\title{
Clinical course of pregnancy and postpartum in a multidrug-resistant tuberculosis/HIV co-infected patient receiving bedaquiline-containing regimen as antimycobacterial therapy
}

\author{
O.M. Raznatovska ${ }^{1}$, S.I. Tertishniy ${ }^{1}$, V.G. Syusyuka ${ }^{1}$, A.V. Fedorec ${ }^{2}$, T.K. Sahaidak ${ }^{2}$, T.A. Grekova ${ }^{1}$, M. O. Shalmina ${ }^{1}$, \\ S.M. Makhonchuk ${ }^{3}$ \\ 1. Zaporizhzhia State Medical University, Zaporizhzhia \\ 2. Zaporizhzhia Regional TB Clinical Dispensary, Zaporizhzhia \\ 3. Zaporizhzhia Regional Pathological Anatomy Bureau, Zaporizhzhia \\ The authors have declared that no competing interests exist.
}

BACKGROUND. According to World Health Organization (WHO), experimental studies performed in rats and rabbits have revealed no evidence of harmful side effects of bedaquiline to the fetus. WHO points out that, given the lack of adequate and controlled studies on the effects of bedaquiline on the fetus in pregnant women, and the fact that drug data regarding teratogenicity are limited to nonclinical animal data, this drug may be used when an effective treatment regimen cannot otherwise be provided. However, WHO recommends thorough registering treatment, pregnancy, and postpartum bedaquiline-related outcomes to provide data on appropriate dosing for multidrug-resistant tuberculosis (MDR-TB) treatment during pregnancy and postpartum. However, in the modern literature, there are no data about attributable to bedaquiline adverse events in MDR-TB/HIV co-infected pregnant women and their fetus as well as during the postpartum period.

OBJECTIVE. To update the literature data with the clinical features of pregnancy and postpartum period in a MDR-TB/ HIV co-infected patient receiving a bedaquiline-containing regimen as antimycobacterial therapy in the third trimester based on an example from own clinical experience.

METHODS. We report the clinical case of pregnancy course in the MDR-TB/HIV co-infected woman treated with the bedaquiline-containing regimen as antimycobacterial therapy in the third trimester.

RESULTS. In the clinical case presented, the patient demonstrated an initial poor adherence to treatment for both MDR-TB and HIV infection resulting in tuberculous process and HIV rapid progression. Since the patient refused the option of undergoing the therapeutic abortion prior to 22 gestational weeks as the pregnancy was intended, the antimycobacterial therapy regimen was modified by bedaquiline inclusion at 30 weeks' gestation (the third trimester) for the maternal and neonatal mortality prevention. However, there was no sputum smear conversion on the antimycobacterial therapy regimen including bedaquiline, the patient presented with the signs of endogenous intoxication and nephropathy. Relatedly, neonatal transabdominal ultrasound revealed intrauterine growth retardation, worsening fetoplacental insufficiency (reverse flow) and intrauterine dystrophy. There was abundant placental calcification. Taking into account breech presentation, II degree intrauterine growth retardation, III degree fetoplacental insufficiency (reverse flow), oligohydramnios, fetal distress syndrome and bilateral pyelectasis, the patient was transferred to the Perinatal Centre for planned caesarean section at the 32 nd week of gestation. The premature female infant was declared dead some hours later. In the postpartum period, the patient continued the initiated bedaquilinebased antimycobacterial therapy and antiretroviral therapy. However, positive clinical-radiological dynamics and sputum smear conversion have not been achieved.

CONCLUSIONS. The clinical case presented confirms the literature data that the features of pregnancy and postpartum period in patients with MDR-TB/HIV co-infection are characterized by such complications development as preterm delivery, early neonatal mortality, intrauterine growth retardation, distress syndrome, etc.

KEY WORDS: pregnancy, multidrug-resistant tuberculosis, HIV, bedaquiline. 


\title{
Перебіг вагітності та післяпологового періоду у хворої на коінфекцію мультирезистентного туберкульозу/ВІЛ на тлі застосування бедаквіліну в режимі антимікобактеріальної терапії
}

\author{
О.М. Разнатовська ${ }^{1}$, С.І. Тертишний ${ }^{1}$, В.Г. Сюсюка ${ }^{1}$,А.В. Федорець ${ }^{2}$, Т.К. Сагайдак², Т.А. Грекова ${ }^{1}$, М.О. Шальміна ${ }^{1}$, С.М. Махончук ${ }^{3}$ \\ 1. Запорізький державний медичний університет, м. Запоріжжя \\ 2. КУ «Запорізький обласний протитуберкульозний клінічний диспансер», м. Запоріжжя \\ 3. КУ «Запорізьке обласне патологоанатомічне бюро», м. Запоріжжя \\ Конфлікт інтересів: відсутній
}

ОБґрунтУвАння. Як зазначає Всесвітня організація охорони здоров’я (ВООЗ), проведені експериментальні дослідження на щурах і кроликах не виявили ознак шкоди бедаквіліну для плода. ВООЗ вказує на те, що, враховуючи відсутність достатньої кількості адекватних і контрольованих досліджень впливу бедаквіліну у вагітних жінок на плід і те, що дослідження на тваринах не завжди прогнозують реакцію людини, цей препарат слід використовувати під час вагітності, тільки якщо це абсолютно необхідно. При цьому ВООЗ рекомендує при застосуванні бедаквіліну ретельно реєструвати результати лікування, вагітності та післяпологового періоду, щоб допомогти в подальших рекомендаціях щодо лікування MDR під час вагітності. На сьогодні в наявній літературі відсутні дані щодо впливу бедаквіліну на плід у вагітних та на перебіг післяпологового періоду в жінок, хворих на коінфекцію мультирезистентного туберкульозу (МР-ТБ)/ВІЛ.

МЕтодИ. Описано клінічний випадок перебігу вагітності і коінфекції МР-ТБ/ВІЛ на тлі застосування бедаквіліну в режимі антимікобактеріальної терапії в ІІІ триместрі вагітності.

PEЗУЛЬтАТИ. У представленому клінічному випадку в пацієнтки визначалася початкова відсутність прихильності до лікування як МР-ТБ, так і ВІЛ, що призвело до швидкого прогресування туберкульозного процесу та ВІЛ. Оскільки від переривання вагітності у період до 22 тижнів пацієнтка категорично відмовилася, бо вагітність була бажаною, то з метою запобігання як материнської, так і неонатальної смерті було прийнято рішення на 30-му тижні вагітності (III триместр) змінити схему антимікобактеріальної терапії з додаванням бедаквіліну Проте на тлі застосування такої схеми антимікобактеріальної терапії та антиретровірусної терапії в пацієнтки зберігалися масивне бактеріовиділення, ендогенна інтоксикація та нефротичні зміни. Паралельно цьому в плода визначалися затримка росту, наростання порушення плодово-плацентарної гемодинаміки з реверсним кровотоком і дистрофія. У плаценті діагностувалися помірно виражені кальцинати. Враховуючи тазове передлежання плода, затримку розвитку плода 2 ступеня, порушення плодово-плацентарної гемодинаміки 3 ступеня (реверсний кровоток), маловоддя, двобічну пієлоектазію в плода та дистрес-синдром плода, на 32-му тижні вагітності пацієнтка була переведена до перинатального центру для проведення розродження шляхом кесаревого розтину. Проте новонароджена через декілька годин померла. У післяпологовому періоді пацієнтка продовжувала призначену антимікобактеріальну терапію, яка включала бедаквілін, та антиретровірусну терапію, однак позитивної клінічно-рентгенологічної динаміки та припинення бактеріовиділення не вдалося досягти.

ВисновКИ. Представлений клінічний випадок підтверджує дані літератури стосовно того, що особливостями перебігу вагітності та післяпологового періоду у хворої на коінфекцію МР-ТБ/ВІЛ є розвиток таких ускладнень, як передчасні пологи, рання неонатальна смерть, внутрішньоутробне обмеження росту плода, дистрес-синдром та ін.

КлючовІ СловА: вагітність, мультирезистентний туберкульоз, ВІЛ-інфекція, бедаквілін.

\section{Течение беременности и послеродового периода}

\section{у больной с коинфекцией мультирезистентного туберкулеза/ВИЧ}

\section{на фоне применения бедаквилина в режиме антимикобактериальной терапии}

\author{
Е.Н. Разнатовская ${ }^{1}$, С.И. Тертышный ${ }^{1}$, В.Г. Сюсюка ${ }^{1}$, А.В. Федорец ${ }^{2}$, Т.К. Сагайдак ${ }^{2}$, Т.А. Грекова ${ }^{1}$, М.А. Шальмина ${ }^{1}$, С.М. Махончук \\ 1. Запорожский государственный медицинский университет \\ 2. КУ «Запорожский областной противотуберкулезный клинический диспансер» \\ 3. КУ «Запорожское областное патологоанатомическое бюро» \\ Конфликт интересов: отсутствует
}

DOI: $10.32902 / 2663-0338-2019-4-23-30$ 


\section{】 клІнІчний дОсвІд}

ОБоСновАНИЕ. Как отмечает Всемирная организация здравоохранения (ВОЗ), проведенные на крысах и кроликах экспериментальные исследования не выявили признаков вреда бедаквилина для плода. ВОЗ указывает на то, что, учитывая отсутствие достаточного количества адекватных и контролируемых исследований влияния бедаквилина у беременных женщин на плод и то, что исследования на животных не всегда предсказывают реакцию человека, этот препарат следует использовать во время беременности, только если это абсолютно необходимо. При этом ВОЗ рекомендует при применении бедаквилина тщательно регистрировать результаты лечения, беременности и послеродового периода, чтобы помочь в дальнейших рекомендациях по лечению MDR во время беременности. На сегодня в существующей литературе отсутствуют данные о влиянии бедаквилина на плод у беременных и течение послеродового периода у женщин, больных коинфекцией мультирезистентного туберкулеза (МР-ТБ)/ВИЧ.

МЕтоДЫ. Описан клинический случай течения беременности и коинфекции МР-ТБ/ВИЧ на фоне применения бедаквилина в режиме антимикобактериальной терапии в III триместре беременности.

PEзУЛЬтАТЫ. В представленном клиническом случае у пациентки определялось начальное отсутствие приверженности к лечению как МР-ТБ, так и ВИЧ, что привело к быстрому прогрессированию туберкулезного процесса и ВИЧ. Поскольку от прерывания беременности в период до 22 недель пациентка категорически отказалась, потому что беременность была желанной, то с целью предотвращения как материнской, так и неонатальной смерти было принято решение на 30-й неделе беременности (III триместр) изменить схему антимикобактериальной терапии с добавлением бедаквилина. Однако на фоне применения такой схемы антимикобактериальной терапии и антиретровирусной терапии у пациентки сохранялись массивное бактериовыделение, эндогенная интоксикация и нефротические изменения. Параллельно этому у плода определялись задержка роста, нарастание нарушения плодово-плацентарной гемодинамики с реверсивным кровотоком и дистрофия. В плаценте диагностировались умеренно выраженные кальцинаты. Учитывая тазовое предлежание плода, задержку развития плода 2 степени, нарушение плодово-плацентарной гемодинамики 3 степени (реверсный кровоток), маловодие, двустороннюю пиелоэктазию у плода и дистресс-синдром плода, на 32-й неделе беременности пациентка была переведена в перинальный центр для проведения родоразрешения путем кесарева сечения. Однако новорожденная через несколько часов умерла. В послеродовом периоде пациентка продолжала назначенную антимикобактериальную терапию, которая включала бедаквилин, и антиретровирусную терапию, но положительной клинико-рентгенологической динамики и прекращения бактериовыделения не удалось достичь.

Выводы. Представленный клинический случай подтверждает данные литературы о том, что особенностями течения беременности и послеродового периода у больных с коинфекцией МР-ТБ/ВИЧ являются развитие таких осложнений, как преждевременные роды, ранняя неонатальная смерть, внутриутробное ограничение роста плода, дистресс-синдром и др.

КЛючєВыє словА: беременность, мультирезистентный туберкулез, ВИЧ-инфекция, бедаквилин.

Introduction. Diseases such as multidrug-resistant tuberculosis (MDR)/extensively drug-resistant tuberculosis (XDR) and human immunodeficiency virus (HIV) are the great global challenges facing humanity today and co-infection provides reciprocal advantages to both pathogens. MDR/XDR-TB is a common opportunistic infection and one of the leading causes of death among HIV-infected patient [1].

Bedaquiline as a part of combined therapy for the treatment of pulmonary tuberculosis in adult patients in case of impossibility of using other effective regimens due to intolerability or resistance was approved by the US Food and Drug Administration (FDA) in 2012 [2].

Guglielmetti L. et al. [3] report in their study very high results of treatment in MDR/XDR-TB patients receiving antimycobacterial therapy (AMBT) including bedaquiline combined with other active drugs, as the rate of culture sputum conversion was $97 \%$.

Ndjeka N. et al. [4] studied the safety and effectiveness of bedaquiline in the AMBT regimen for HIV-infected patients with XDR-TB also receiving antiretroviral therapy (ART). Based on the findings, researchers suggested that bedaquiline may be both efficacious and safe in this category of patients on ART.
According to World Health Organization (WHO), experimental studies performed in rats and rabbits have revealed no evidence of harmful side effects of bedaquiline to the fetus. WHO points out that, given the lack of adequate and controlled studies on the effects of bedaquiline on the fetus in pregnant women, and the fact that drug data regarding teratogenicity are limited to nonclinical animal data, this drug may be used when an effective treatment regimen cannot otherwise be provided [5]. However, WHO recommends thorough registering treatment, pregnancy, and postpartum bedaquiline-related outcomes to provide data on appropriate dosing for MDR-TB treatment during pregnancy and postpartum [1].

Following a literature review [6], we concluded that pregnant women with tuberculosis (TB) infection have a significantly higher risk of developing complications such as premature birth, maternal and perinatal mortality and neonatal outcomes include intrauterine growth retardation, congenital anomalies, respiratory distress syndrome and other. Based on these facts, most researchers recommend the initiation of second-line drugs for MDR-TB according to drug susceptibility test (DST) results since the second trimester of pregnancy avoiding amikacin, streptomycin, prothionamide 
and ethionamide, as a timely and adequate AMBT regimen is a key to the successful pregnancy outcome. Only interdisciplinary team approach is possible for management of pregnancy in such women. Since there is limited data on the safety of bedaquiline in pregnancy for MDR/XDR-TB treatment, therefore it should be avoided as claimed by Rohilla M. et al. [7]

Jaspard M. et al. [8] studied AMBT regimen including bedaquiline, linezolid, para-aminosalicylic acid, cycloserine, levofloxacin in XDR-TB pregnant women and showed safety of this combination in last trimester as the patient delivered a healthy girl. The authors indicated that it was the only case in their experience and the woman was started on this regimen only 3 weeks before delivery.

In the literature available, we have found the only work [9] reporting 3 cases of a pregnancy course in pregnant MDR-TB/ HIV co-infected women. All three pregnant women received AMBT (without bedaquiline) based on the DST data. It was found that one woman had a spontaneous abortion, one gave birth prematurely and two newborns were diagnosed with intrauterine growth retardation.

However, in the modern literature, there are no data about attributable to bedaquiline adverse events in MDR-TB/HIV co-infected pregnant women and their fetus as well as during the postpartum period.

Objective. To update the literature data with the clinical features of pregnancy and postpartum period in a MDR-TB/ HIV co-infected patient receiving a bedaquiline-containing regimen as antimycobacterial therapy in the third trimester based on an example from own clinical experience.

Materials and methods. We report the clinical case of pregnancy course in the MDR-TB/HIV co-infected woman treated with the bedaquiline-containing regimen as antimycobacterial therapy in the third trimester. The patient received inpatient treatment in the Department of Pulmonary Tuberculosis No 3 of the Clinical Site of Phthisiology and Pulmonology Department of ZSMU at the Municipal Institution «Zaporizhzhia Regional Tuberculosis Clinical Dispensary (ZRTBCD)».

A 35-year-old woman was diagnosed HIV-positive during the first pregnancy in 2008. ART adherence was poor with repeated interruptions in a treatment. HIV status was complicated by tuberculosis during the second pregnancy in 2012. She was on ART only during pregnancy and did not receive it after childbirth, but an AMBT regimen was completed. In 2015, she relapsed with a MDR strain and was given 3 regimens of AMBT but experienced treatment failure due to interruptions in the treatment. The patient was considered for palliative treatment in 2017. Gravida 3, para 2. Children were not subjected to regular medical check-up due to being HIV-negative. She has been married. The patient denied any history of alcohol consumption, but had a smoking history of half a pack of cigarettes a day for 20 years.

Treatment outcomes and follow-up. The patient was admitted to the ZRTBCD at the 16th week of gestation. She was informed of a risk and the option of undergoing a therapeutic abortion prior to 22 gestational weeks has been proposed owing to the severity and progression of the specific process as well as MDR-TB/HIV co-infection. Nonetheless, she decided to continue with the pregnancy as it was intended.

On admission, the patient complained of productive cough, two episodes of spitting blood, exertional dyspnea and subfebrile temperature.
Auscultation of the chest revealed bilateral harsh breathing, no rales. A sputum sample analysis was smear-positive for acid-fast bacilli (AFB) (3+).

Chest X-ray demonstrated a destructive lesion of $8.0 \mathrm{~cm}$ in diameter surrounded by fibrosis in the apex of the right lung with convexity facing towards the lung hilum and a destructive lesion of $2.0 \mathrm{~cm}$ in diameter in the $\mathrm{S} 6$ segment. There were bilateral focal infiltrations of all lung fields and diffuse fibrosis.

Clinical blood analysis (CBA) was as follows: hemoglobin $(\mathrm{Hb})-123 \mathrm{~g} / \mathrm{l}$; erythrocytes $(\mathrm{Er})-3,75 \times 10^{12} / \mathrm{l}$, leukocytes $(\mathrm{L})$ $7,2 \times 10^{9} /$, erythrocyte sedimentation rate (ESR) $-46 \mathrm{~mm} / \mathrm{h}$, banded (b) $-6 \%$, segmented (s) - $55 \%$, eosinophils (e) $-3 \%$, lymphocytes $(\mathrm{l})-30 \%$, monocytes $(\mathrm{m})-6 \%$.

On admission to the ZRTBCD, the patient was receiving palliative care. The management of pregnancy necessitated AMBT initiation for MDR-TB based on the DST result and concurrent ART was started.

The patient was provided with detailed and referenced information as to HIV infection and its outcomes, ART adherence, prevention of mother to child HIV transmission, treatment of opportunistic infection and family planning.

However, at 30 weeks of gestation, she was sputum smear-positive and presented the negative clinical and radiological dynamics.

Transabdominal ultrasound (US) showed 32 weeks of pregnancy, fetal heart rate (HR) was $150 \mathrm{bpm}$, there was adequate amniotic fluid, placental thickness was $30 \mathrm{~mm}$ with moderate focal calcification, breech presentation, early intrauterine growth retardation (IUGR).

US of the urinary system revealed echo signs of right-sided nephroptosis and caliectasis, HIV-associated bilateral diffuse parenchymatous renal changes.

US of the thyroid gland identified echo signs of diffuse changes.

CBA: Hb - $114 \mathrm{~g} / \mathrm{L} ; \mathrm{Er}-3,75 \times 10^{12} / \mathrm{L}, \mathrm{L}-9,5 \times 10^{9} / \mathrm{L}, \mathrm{ESR}-$ $52 \mathrm{~mm} / \mathrm{h}, \mathrm{b}-10 \%$, s - $49 \%$, e - $9 \%, \mathrm{l}-28 \%, \mathrm{~m}-4 \%$.

Biochemical blood tests (urea and electrolytes): creatinine $-80,3 \mu \mathrm{mol}$ (reference interval 95-110 $\mu \mathrm{mol}$ ), urea $3,8 \mathrm{mmol} / \mathrm{L}$ (reference interval 2,5-8,3 mmol/L), serum urea nitrogen concentration $-1,7 \mathrm{mmol} / \mathrm{L}$ (reference interval 14,3 $28,6 \mathrm{mmol} / \mathrm{L}$ ); potassium - 4,3 mmol/L (reference interval 3,5-5,5 mmol/L), sodium - 134,1 mmol/L (reference interval $136-145 \mathrm{mmol} / \mathrm{L}$ ), chloride $-102,2 \mathrm{mmol} / \mathrm{L}$ (reference interval 98-107 mmol/L).

Liver function tests: total bilirubin - 9,8 $\mu$ mol (reference interval 8,6-20,5 $\mu \mathrm{mol}$ ), thymol turbidity test - 18 (reference interval 0-5), alanine aminotransferase (ALT) - 0,13 mmol/h/L (reference interval 0,1-0,68 $\mathrm{mmol} / \mathrm{h} / \mathrm{L}$ ), aspartate transainase (AST) - 0,37 mmol/h/L (reference interval 0,1-0,45 mmol/h/L), total protein - 63,8 $\mathrm{g} / \mathrm{L}$ (reference interval $65-85 \mathrm{~g} / \mathrm{L}$ ).

The CD4+ T-lymphocyte count was 165 cells, viral load 49040 RNA copies/ml).

Electrocardiogram (ECG): adequate voltage, low-voltage in the standard leads. Sinus tachycardia, HR104 bpm. $\mathrm{QTc}=346 \mathrm{~m} / \mathrm{sec}$.

An urologist consultation: chronic non-specific pyelonephritis in a remission stage.

Taking into account the progressive course of both the specific process and HIV infection, bedaquiline was considered for inclusion in the AMBT regimen (bedaquiline, linezolid, 
clofazimine, meropenem, amoxiclav) at 30 weeks' gestation (the third trimester) for the treatment of life-threatening conditions in the patient and according to the present history of MDR-TB treatment based on DST results.

Fetal US was repeated every 4 days: regular fetal HR, 140 bpm.

Her findings on examination at 31 weeks of gestation were as follows:

CBA: $\mathrm{Hb}-114 \mathrm{~g} / \mathrm{l} ; \mathrm{Er}-3,46 \times 10^{12} / \mathrm{L}, \mathrm{L}-8,6 \times 10^{\%} / \mathrm{L}, \mathrm{ESR}-$ $61 \mathrm{~mm} / \mathrm{h}, \mathrm{b}-12 \%, \mathrm{~s}-81 \%$, e - 0 \%, l - $5 \%, \mathrm{~m}-2 \%$.

Laboratory data showed serum amylase level $-8,29 \mathrm{~g} / \mathrm{L}^{*} \mathrm{~h}$ (reference interval 3,3-8,9 8,6 g/L*h).

Laboratory coagulation tests: blood fibrin level - $21 \mathrm{mg}$, blood fibrinogen level $-466 \mathrm{mg} \%$, plasma recalcification time $255^{\prime \prime}$ (reference interval 60-180"), prothrombin ratio $83,7 \%$ (reference interval 80-100\%), hematocrit - 40/60 (reference interval 45/55).

Biochemical blood tests (urea and electrolytes): creatinine $97,2 \mu \mathrm{mol}$, urea $-6,6 \mathrm{mmol} / \mathrm{L}$, serum urea nitrogen concentration - 3,1 mmol/L; potassium - 4,3 mmol/L, sodium $134 \mathrm{mmol} / \mathrm{L}$, chloride - $102,2 \mathrm{mmol} / \mathrm{L}$.

Fasting glucose test $-5,0 \mathrm{mmol} / \mathrm{L}$.

ECG: moderately low-voltage. Sinus tachycardia, HR98 bpm. QTc $=363 \mathrm{~m} / \mathrm{sec}$.

A Y-site injection port was implemented on the left. The patient complained of dyspnea and short of breath feeling in the postoperative period. The chest X-ray revealed left-sided pneumothorax and half-collapsed lung on the same day.

A pleural puncture was performed. Bülau drainage was done.

Two days later, repeat chest X-ray showed almost total re-expansion of the collapsed lung, chest drainage system.

There was no sputum culture conversion (AFB3+).

Her findings on examination at 32 weeks of gestation were as follows:

Transabdominal US showed 32 weeks of pregnancy, fetal HR163 bpm, fetal weight $1000 \mathrm{~g}$, breech presentation, I degree IUGR, reduced amniotic fluid volume, placental thickness of $38 \mathrm{~mm}$ with abundant calcification, III degree fetoplacental insufficiency (reverse flow), intrauterine dystrophy.

CBA: $\mathrm{Hb}-105 \mathrm{~g} / \mathrm{L} ; \mathrm{Er}-3,19 \times 10^{12} / \mathrm{L}, \mathrm{L}-8,4 \times 10^{9} / \mathrm{L}, \mathrm{ESR}-$ $61 \mathrm{~mm} / \mathrm{h}, \mathrm{b}-12 \%, \mathrm{~s}-78 \%, \mathrm{e}-0 \%, \mathrm{l}-8 \%, \mathrm{~m}-2 \%$.

Biochemical blood tests (electrolytes): potassium 4,52 mmol/L, sodium - $136 \mathrm{mmol} / \mathrm{L}$, chloride - 99,7 mmol/L.

Laboratory coagulation tests: blood fibrin level $-16 \mathrm{mg}$, blood fibrinogen level $-355 \mathrm{mg} \%$, prothrombin ratio $92 \%$, hematocrit $-40 / 60$.

Liver function tests: total bilirubin - 11,5 $\mu \mathrm{mol}$, thymol turbidity test $-16,7, \mathrm{ALT}-0,39 \mathrm{mmol} / \mathrm{h} / \mathrm{L}, \mathrm{AST}-0,51 \mathrm{mmol} / \mathrm{h} / \mathrm{L}$, total protein $-74,1 \mathrm{~g} / \mathrm{L}$.

Serum amylase level $-5,3 \mathrm{~g} / \mathrm{L}^{*} \mathrm{~h}$.

ECG: moderately low-voltage. Sinus tachycardia, HR94 bpm. Diffuse left ventricular myocardial changes. QTc $=372 \mathrm{~m} / \mathrm{sec}$.

\section{There was no sputum culture conversion}

Based on fetal US findings, the patient was transferred to a Perinatal Centre for planned caesarean section.

On gynecologist examination: gravida 3 (32 gestational weeks), para 3, breech presentation, II degree IUGR, III degree fetoplacental insufficiency (reverse flow), oligohydramnios, fetal bilateral pyelectasis, fetal distress syndrome, I degree anemia of pregnancy; HIV infection, VI clinical stage, severe immunosuppression, pulmonary MDR-TB.

On the following day, the planned caesarean section was performed. A premature female infant was delivered weighing $1240 \mathrm{~g}$, the length was $44 \mathrm{~cm}$ with Apgar scores of 4 at $1 \mathrm{~min}$ and 5 at $5 \mathrm{~min}$. The newborn developed respiratory distress syndrome with increasing sings of severe breathing disorders. Despite immediate neonatal resuscitation, she was declared dead some hours later.

Fetal autopsy report. Diagnosis on admission to the Perinatal Centre: gravida 3, para 3 (32 gestational weeks), breech presentation. Caesarean section.

\section{Final clinical diagnosis}

The main diagnosis: early-onset neonatal bacterial sepsis associated with maternal tuberculosis and HIV infection, immunodeficiency, respiratory distress syndrome of preterm neonate mixed-type (pulmonary atelectasis).

Complications: III degree respiratory failure. Acute renal failure, stage of anuria. Ascites. Right-sided pleuritis. Left-sided pneumothorax. Bülau drainage.

Secondary diagnosis: neonatal hypoxic-ischemic encephalopathy, cerebral depression syndrome.

\section{Pathologic-anatomical diagnosis:}

The main diagnosis: neonatal respiratory distress syndrome: hyaline membranes, primary pulmonary atelectasis.

Complications: acute congestion and dystrophy of internal organs, cerebral edema.

Secondary diagnosis: prematurity (birth weight $1240 \mathrm{~g}$, gestational age 32 weeks).

Histopathological examination of the autopsy material: pulmonary congestion and immaturity, fragments of hyaline membranes, desquamated epithelium and blood in the airspaces, focal intraalveolar hemorrhage, focal atelectasis, disatelectasis, edema of interalveolar septa. Congestion and dystrophy of other organs (the liver, myocardium and kidney).

Histopathological study of the placenta: lymphocytic and histiocytic infiltration, calcifications, necrotic and degenerative zones in the basal layer of decidua.

Clinical and pathologic-anatomical epicrisis: female infant. Neonatal respiratory distress syndrome (hyaline membranes with primary pulmonary atelectasis).

The patient was transferred to the ZRTBCD to continue the basic treatment course for MDR-TB/HIV co-infection in 4 days.

The AMBT regimen remained the same: bedaquiline, linezolid, clofazimine, meropenem, amoxiclav.

The chest X-ray demonstrated negative dynamics caused by an increase in the number of focal infiltrations and destructions (Fig. 1). There were bilateral polymorphic focal opacities with areas of consolidation in all lung fields, cavities with a diameter of $8.0 \mathrm{~cm}$ with thickened walls in the apex and of $1,5 \mathrm{~cm}$ in the $\mathrm{S} 6$ in the right lung. Multiple focuses of destruction ranging from 1,0 to $3,0 \mathrm{~cm}$ in diameter and a shadow of $Y$-site injection port in situ were found in the left lung.

Fasting glucose test $-3,78 \mathrm{mmol} / \mathrm{L}$.

Serum amylase level $-8,72 \mathrm{~g} / \mathrm{L}^{*} \mathrm{~h}$.

Biochemical blood tests (electrolytes): potassium $3,2 \mathrm{mmol} / \mathrm{L}$, sodium - 131,5 mmol/L, chloride - 100,9 mmol/L. 


\section{】 клІнІчний дОсвІд}

Biochemical blood tests (urea): creatinine - 123,8 $\mu \mathrm{mol}$, urea $-5,06 \mathrm{mmol} / \mathrm{L}$, serum urea nitrogen concentration $2,36 \mathrm{mmol} / \mathrm{L}$.

Laboratory coagulation tests: blood fibrin level - $26 \mathrm{mg}$, blood fibrinogen level $-577,2 \mathrm{mg} \%$, plasma recalcification time $124,5^{\prime \prime}$, prothrombin ratio $90,9 \%$, hematocrit $-40 / 60$.

CBA: $\mathrm{Hb}-113 \mathrm{~g} / \mathrm{l} ; \mathrm{Er}-3,52 \times 10^{12} / \mathrm{l}, \mathrm{L}-9,2 \times 10^{9} / \mathrm{l}, \mathrm{ESR}-$ $46 \mathrm{~mm} / \mathrm{h}, \mathrm{b}-8 \%, \mathrm{~s}-62 \%, \mathrm{e}-4 \%, \mathrm{l}-21 \%, \mathrm{~m}-5 \%$.

Liver function tests: total bilirubin - 10,4 $\mu \mathrm{mol}$, thymol turbidity test $-5,35$, ALT $-0,65 \mathrm{mmol} / \mathrm{h} / \mathrm{L}, \mathrm{AST}-0,38 \mathrm{mmol} / \mathrm{h} / \mathrm{L}$, total protein $-64,1 \mathrm{~g} / \mathrm{L}$.

A week after delivery, US revealed echo signs of diffuse parenchymal changes of the liver and pancreas, right-sided nephroptosis, bilateral diffuse parenchymatous renal changes, chronic pyelonephritis, enlarged uterus, right-sided exudative pleuritis (pleural effusion of $180 \mathrm{~cm}^{3}$ ).

There was no sputum culture conversion (AFB3+) in 3,5 months after AMBT including bedaquiline initiation.

The chest X-ray showed no dynamics (Fig. 2). There were bilateral multiple polymorphic focal opacities in all lung fields with areas of consolidation in the right lower lobe of the lung and destructions ranging from 1,5 to 8,0 $\mathrm{cm}$ in diameter; both lung hilum were infiltrated, sinuses were free.

Biochemical blood tests (electrolytes): potassium $5,03 \mathrm{mmol} / \mathrm{L}$, sodium - 138,1 mmol/L, calcium - 0,89 mmol/L, chloride - 98,28 mmol/L.

Biochemical blood tests (urea): creatinine $-107,7 \mu \mathrm{mol}$, urea - 5,19 mmol/L, serum urea nitrogen concentration 2,42 $\mathrm{mmol} / \mathrm{L}$.

Liver function tests: total bilirubin - 9,1 $\mu \mathrm{mol}$, thymol turbidity test $-20, A L T-0,61 \mathrm{mmol} / \mathrm{h} / \mathrm{L}, \mathrm{AST}-0,53 \mathrm{mmol} / \mathrm{h} / \mathrm{L}$, total protein $-65 \mathrm{~g} / \mathrm{L}$.

CBA: $\mathrm{Hb}-124 \mathrm{~g} / \mathrm{l} ; \mathrm{Er}-3,85 \times 10^{12} / \mathrm{l}, \mathrm{L}-6,1 \times 10^{9} / \mathrm{L}, \mathrm{ESR}-$ $39 \mathrm{~mm} / \mathrm{h}, \mathrm{b}-6 \%$, s - $61 \%$, e - $3 \%, \mathrm{l}-30 \%, \mathrm{~m}-4 \%$.

CD3+ T-lymphocyte count was $91,61 \%$ (reference interval 55-84 \%), CD3/CD4 T-lymphocyte - 13,32 \% (reference interval 31-60\%).

The examination data after 4,5 months after AMBT including bedaquiline initiation. Samples of sputum were again smear-positive for AFB (3+).

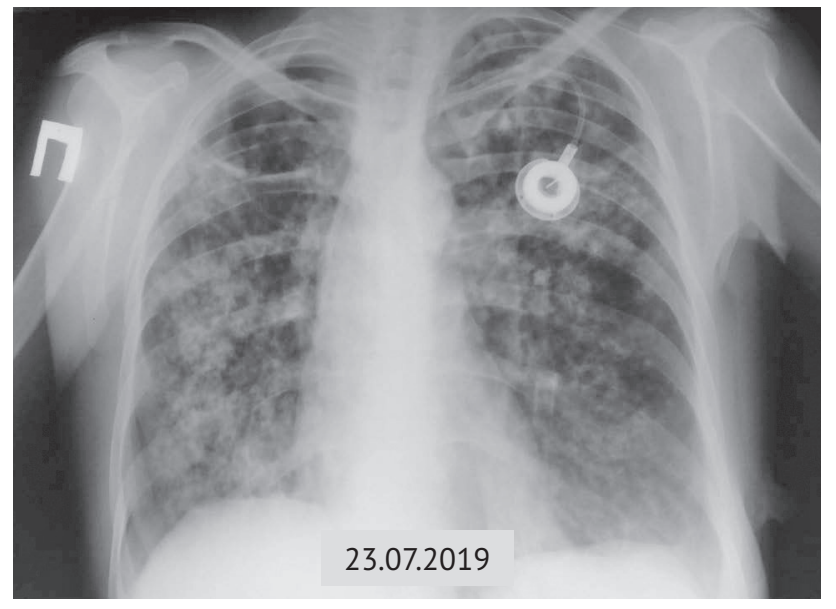

Fig. 1. Chest radiograph on the 4th day after delivery and in 2 months after AMBT including bedaquiline initiation
Biochemical blood tests (urea): creatinine - 184,5 $\mu \mathrm{mol}$, urea $-5,0 \mathrm{mmol} / \mathrm{L}$, serum urea nitrogen concentration 2,33 mmol/L.

CBA: $\mathrm{Hb}-122 \mathrm{~g} / \mathrm{l} ; \mathrm{Er}-3,85 \times 10^{12} / \mathrm{L}, \mathrm{L}-9,6 \times 10^{9} / \mathrm{L}, \mathrm{ESR}-$ $48 \mathrm{~mm} / \mathrm{h}, \mathrm{b}-4 \%, \mathrm{~s}-57 \%, \mathrm{e}-0 \%, \mathrm{l}-31 \%, \mathrm{~m}-8 \%$.

Liver function tests: thymol turbidity test $-20,2, \mathrm{ALT}-0,95$ $\mathrm{mmol} / \mathrm{h} / \mathrm{L}$, AST - 0,59 mmol/h/L, total protein - $67 \mathrm{~g} / \mathrm{L}$.

Biochemical blood tests (electrolytes): potassium - 4,81 $\mathrm{mmol} / \mathrm{L}$, sodium - 133,7 mmol/L, chloride - 98,1 mmol/L.

Serum amylase level $-4,68 \mathrm{~g} / \mathrm{L}^{*} \mathrm{~h}$.

Microbiological examination of sputum samples (smear microscopy): AFB3+.

Today, the patient has continued the treatment, however, clinical and radiological dynamics has not observed.

The case study. In the clinical case presented, the patient demonstrated an initial poor adherence to treatment for both MDR-TB and HIV infection resulting in tuberculous process and HIV rapid progression. The patient was admitted to the clinic at the 16th week of gestation on palliative care and without receiving ART (voluntarily). Only from that moment, she was initiating the comprehensive treatment for MDR-TB/HIV co-infection (AMBT + ART) being profoundly immunosuppressed (CD4 T-lymphocyte count -165 cells, viral load - 49040 RNA copies/ml) and sputum smear-positive with marked infiltrative-destructive changes in the lungs.

Since the patient refused the option of undergoing the therapeutic abortion prior to 22 gestational weeks as the pregnancy was intended, the AMBT regimen was modified by bedaquiline inclusion (bedaquiline, linezolid, clofazimine, meropenem, amoxiclav) at 30 weeks' gestation (the third trimester) for the maternal and neonatal mortality prevention.

At 31 weeks of gestation, the Y-site injection port was implemented on the left that caused the left-sided pneumothorax and half-collapsed lung. The pleural puncture was performed on the left and Bülau drainage was done.

However, there was no sputum smear conversion on the AMBT regimen including bedaquiline, the patient presented with the signs of endogenous intoxication and nephropathy. Relatedly, neonatal US revealed IUGR, worsening fetoplacental insufficiency (reverse flow) and intrauterine dystrophy. There was abundant placental calcification.

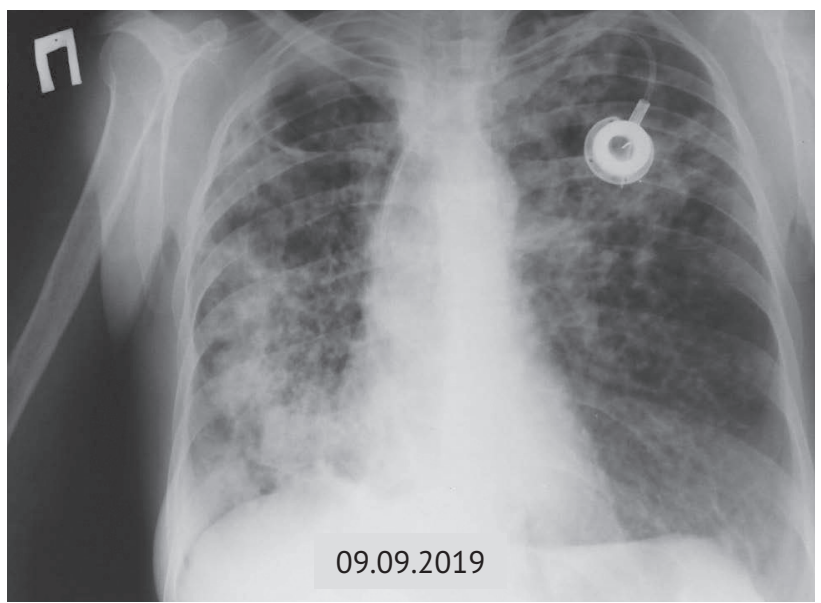

Fig. 2. Chest radiograph in 3,5 months after AMBT including bedaquiline initiation 


\section{【 кЛІнІчний дОсвІд}

Taking into account breech presentation, II degree IUGR, III degree fetoplacental insufficiency (reverse flow), oligohydramnios, fetal distress syndrome and bilateral pyelectasis, the patient was transferred to the Perinatal Centre for planned caesarean section at the $32 \mathrm{nd}$ week of gestation. The premature female infant was declared dead some hours later.

The patient in the clinical case presented as well as in the case described by Jaspard M. et al. [8], was given with additional bedaquiline in the AMBT regimen since the third trimester of pregnancy and only 3 weeks before the delivery. However, in contrast to the above-mentioned work, our patient received such drug combination at the beginning of the third trimester for the treatment of life-threatening conditions, and the counterparts reported on the treatment regimen initiation at the end of the third trimester of pregnancy. Although, in the case presented, the fetal autopsy revealed neither tuberculosis nor HIV infection on the AMBT regimen including bedaquiline, histopathological study of the placenta revealed lymphocytic and histiocytic infiltration, calcifications, necrotic and degenerative zones in the basal layer of decidua. Furthermore, the clinical and pathologic-anatomical epicrisis pointed that newborn developed neonatal respiratory distress syndrome (hyaline membranes with primary pulmonary atelectasis) and the immediate cause of death was pulmonary heart disease.

It is of interest to note that among the 3 pregnant women with MDR-TB/HIV co-infection not receiving bedaquiline-based treatment regimen, studied by Khan M. et al. [9], one woman had a spontaneous abortion, one gave birth prematurely and two newborns were diagnosed with IUGR. In this particular case, the infant was also delivered prematurely and diagnosed with IUGR, but due to much more serious fetal outcomes.

In the postpartum period, the patient continued the initiated bedaquiline-based AMBT and ART. However, positive clinical-radiological dynamics and sputum smear conversion have not been achieved.

\section{Conclusions}

The clinical case presented confirms the literature data that the features of pregnancy and postpartum period in patients with MDR-TB/HIV co-infection are characterized by such complications development as preterm delivery, early neonatal mortality, intrauterine growth retardation, distress syndrome, etc. In this case, the bedaquiline-containing regimen as antimycobacterial therapy has failed to prevent early neonatal mortality (neonatal autopsy revealed hyaline membranes with primary pulmonary atelectasis, the immediate cause of death pulmonary heart disease). In the postpartum women on this treatment regimen, positive clinical-radiological dynamics and sputum smear conversion have not been achieved. Given the stable critical condition of the patient caused by MDR-TB/HIV co-infection, profound immunosuppression, marked infiltrative-destructive changes in the lungs, smear-positive sputum sample analysis, endogenous intoxication and nephropathy throughout the pregnancy, no overall conclusions on potential teratogenecity of bedaquiline can be derived. Therefore, such cases should be further studied. 


\section{КЛІнІчнИй ДОСвІД}

\section{References}

1. Global Tuberculosis Report 2018. Geneva - World Health Organization 2019: 174

2. Cox EM. FDA accelerated approval letter to Janssen Research and Development. Washington, DC: Food and Drug Administration. 2012. Available from: http://www.accessdata.fda.gov/drugsatfda_docs/appletter/2012/2043840rig1s000ltr.pdf.

3. Guglielmetti L, Le Dû D, Jachym M, Henry B, Martin D, Caumes E, et al. MDR-TB Management Group of the French National Reference Center for Mycobacteria and the Physicians of the French MDR-TB Cohort. Compassionate use of bedaquiline for the treatment of multidrug-resistant and extensively drug-resistant tuberculosis: interim analysis of a French cohort. Clin Infect Dis. 2015; 60: 188-94. DOI: 10.1093/cid/ciu786.

4. Ndjeka N, Conradie F, Schnippel K, Hughes J, Bantubani N, Ferreira H, et al. Treatment of drug-resistant tuberculosis with bedaquiline in a high HIV prevalence setting: an interim cohort analysis. Int J Tuberc Lung Dis. 2015; 19 (8): 979-85. DOI: 10.5588/ijtld.14.0944.
5. Companion Handbook to the WHO Guidelines for the Programmatic Management of Drug-Resistant Tuberculosis: ANNEX 4"How-to" guide on the use of bedaquiline for MDR-TB treatment. Geneva: World Health Organization. 2014:331-358. PMID: 25320836.

6. Raznatovska OM, Shalmin OS. Features of pregnancy course in women with chemoresistant tuberculosis (a literature review). Запорізький медичний журнал. 2019; 5 (116): 691-696. DOI: 10.14739/2310-1210. 2019.5.179473.

7. Rohilla M, Joshi B, Jain V, Kalra J, Prasad GRV. Multidrug-Resistant Tuberculosis during Pregnancy: Two Case Reports and Review of the Literature. Case Rep Obstet Gynecol. 2016. DOI: 10.1155/2016/1536281.

8. Jaspard M, Elefant-Amoura E, Melonio I, De Montgolfier I, Veziris N, Caumes E. Bedaquiline and Linezolid for Extensively Drug-Resistant Tuberculosis in Pregnant Woman. Emerg Infect Dis. 2017; 23 (10): 1731-1732. DOI: 10.3201/ eid2310.161398.

9. Khan M, Pillay T, Moodley J, Ramjee A, Padayatchi N. Pregnancies complicated by multidrug-resistant tuberculosis and HIV co-infection in Durban, South Africa. IJTLD. 2007; 11 (6): 706-708.

\section{Raznatovska Olena Mykolaivna}

Head of the Department of Phthisiology and Pulmonology,

Zaporizhzhya State Medical University.

MD, PhD, Professor

2 Perspectyvna Street, Zaporizhzhya, 69035, Ukraine.

ORCID iD: orcid.org/0000-0003-2252-9063

.

ORCID iD: orcid.org/0000-0003-2252-9063

\section{Тертишний Сергій Ігорович}

Завідувач кафедри патологічної анатомії і судової медицини

Запорізького державного медичного університету.

Д-р мед. наук, професор.

26, просп. Маяковського, м. Запоріжжя, 69000, Україна.

ORCID iD: orcid.org/0000-0003-3856-4234

\section{Сюсюка Володимир Григорович}

Доцент кафедри акушерства і гінекології

Запорізького державного медичного університету.

Д-р мед. наук.

26, просп. Маяковського, м. Запоріжжя, 69000, Україна.

ORCID iD: orcid.org/0000-0002-3183-4556

\section{Федорець Андрій Васильович}

Завідувач відділення легеневого туберкульозу № 3

$К У$ «Запорізький обласний протитуберкульозний клінічний диспансер».

2, вул. Перспективна, м. Запоріжжя, 69000, Україна.

ORCID iD: orcid.org/0000-0003-0994-5265

Сагайдак Тетяна Констянтинівна

Відділення легеневого туберкульозу № 3

КУ «Запорізький обласний протитуберкульозний клінічний диспансер».

2, вул. Перспективна, м. Запоріжжя, 69035, Україна.

ORCID iD: https://orcid.org/0000-0003-0412-0782

\section{Грекова Тетяна Анатоліївна}

Доцент кафедри патологічної фізіології

Запорізького державного медичного університету.

Канд. мед. наук.

31, вул. Сталеварів, м. Запоріжжя, 69035, Україна.

ORCID iD: orcid.org/0000-0001-9946-3336

\section{Шальміна Марія Олександрівна}

Асистент кафедри клінічної фармакології, фармації, фармакотерапії і косметології Запорізького державного медичного університету. Канд. мед. наук.

34, вул. Сталеварів, м. Запоріжжя, 69035, Україна.

ORCID iD: orcid.org/0000-0002-4364-6106

\section{Махончук Сергій Миколайович}

Завідувач відділення

КУ «Запорізьке обласне патологоанатомічне бюро».

10, Оріхівське шосе, м. Запоріжжя, 69000, Україна.

\section{Tertishniy Sergii lhorovych}

Head of the Department of Pathological Anatomy and Forensic Medicine, Zaporizhzhya State Medical University.

MD, PhD, Professor.

26 Mayakovskogo Street, Zaporizhzhya, 69000, Ukraine. ORCID iD: orcid.org/0000-0003-3856-4234.

\section{Syusyuka Volodymyr Grygorovych}

Associate Pofessor of the Department of Obstetrics and Gynecology, Zaporizhzhya State Medical University.

$M D, P h D$.

26 Mayakovskogo Street, Zaporizhzhya, 69000, Ukraine. ORCID iD: orcid.org/0000-0002-3183-4556

\section{Fedorec Andrii Vasyliovych}

Head of Pulmonary Tuberculosis Department No 3,

Municipal Institution «Zaporizhzhya Regional TB Clinical Dispensary».

2 Perspectyvna Street, Zaporizhzhya, 69035, Ukraine.

ORCID iD: orcid.org/0000-0003-0994-5265.

\section{Sahaidak Tetiana Kostiantynivna}

Department of Pulmonary Tuberculosis No 3,

Municipal Institution «Zaporizhzhya Regional TB Clinical Dispensary».

2 Perspectyvna Street, Zaporizhzhya, 69035, Ukraine.

ORCID iD: orcid.org/0000-0003-0412-0782

\section{Grekova Tetyana Anatoliivna}

Assistant Professor of Department of Pathological Physiology,

Zaporizhzhya State Medical University.

PhD.

31 Stalevariv St, Zaporizhzhya, 69035, Ukraine.

ORCID iD: orcid.org/0000-0001-9946-3336

\section{Shalmina Mariia Olexandrivna}

Assistant Professor, Department of Clinical Pharmacology, Pharmacy, Pharmacotherapy and cosmetology, Zaporizhzhya State Medical University. PhD.

34 Stalevariv Street, Zaporizhzhya, 69035, Ukraine.

ORCID: orcid.org/0000-0002-4364-6106

\section{Makhonchuk Sergii Mykolaiovych}

Head of the department,

Municipal Institution "Zaporizhzhia Regional Pathological and Anatomy Bureau». 10 Orikhivske Shose, Zaporizhzhya, 69000, Ukraine. 